\title{
The Persistence of Fenitrothion Insecticide in Red Maple (Acer rubrum L.) and White Birch (Betula papyfifera (Marsh.)) Deer
}

Browse

\section{L.E. LAPIERRE}

\section{Abstract}

From May 15 to November 15, 1977, vegetation plots were monitered on a constant basis in order to obtain the concentration of fenitrothion in red maple and white birch deer browse. The data obtained indicates that the concentrations tend to be as high as 21.413 ppm for the red maple and $19.371 \mathrm{ppm}$ for the white birch immediately following the spray application. However, the concentrations are below $0.010 \mathrm{ppm} 120$ days following the application. Fenitroxon was detected in two of the samples taken from the sprayed plots. None was detected within the control plots. There is no evidence in the literature that a concentration of fenitrothion of the magnitude detected would have obvious effects on deer populations during their winter yarding.

Fenitrothion, O, O-dimethyl O-(4 nitro-m-tolyl) phosphorothioate, has been used since 1969 to control spruce budworm (Choristoneura fumiferama (Clemens)) in the forest of the Canaan Game Reserve, New Brunswick, Canada. Various workers (Shishido et al. 1972, Miyamoto 1969, Nigam et al. 1971) have previously shown the short persistence and fate of fenitrothion in a natural

Author is with the Biology Department, Université de Moncton, Moncton, N.B., EIA 3E9, Canada.

This study was conducted under support funds received from Forest Protection Limited and the Conseil de Recherche de l'Université de Moncton. Their support is greatly appreciated. I also thank the staff of the Chemistry Department, particularly Dr. Victorin Mallet for his assistance with the analytical work. I am also grateful to all who have assisted me during the project. environment. Furthermore Yule and Duffy (1972) and Sundaram (1974) demonstrated that fenitrothion can persist in a coniferous forest in concentration ranging from 0.80 to 0.14 ppm over a 5 -year period.

This project evaluated residual concentrations of fenitrothion and its oxygen analogue in red maple (Acer rubrum) and white birch (Betula papyrifera (L.)). Previous studies by Crête (1976) and unpublished data obtained by the author from monitoring deer yards in southeastern New Brunswick indicate that red maple and white birch play an important role in the diet of the white-tailed deer (Odocoileus virginianus (Zimmerman)) during the winter yarding. It was anticipated that a high concentration of fenitrothion might have a negative effect on the intestinal rumen flora and consequently disrupt the energy requirements of the deer during their winter yarding.

\section{Study Area and Methods}

The field experiments were located in the Canann Game Reserve area $34 \mathrm{~km}$ northwest of Moncton within longitude $65^{\circ} 30^{\prime}$ and latitude $46^{\circ} 20^{\prime}$. The experimental spray plot was located $5 \mathrm{~m}$ from Alward Brook inside spray block 279 of the 1977 spray program. The control plot was located along the south side of the Canaan River approximately $17 \mathrm{~km}$ from the sprayed plot. The control plot was not sprayed during the 1975,1976 , and 1977 programs. 
The sampling plots were surrounded by forested aeas dominated by red spruce (Picea rubens (Moench)), and black spruce (Picea mariana (L.) (M.II)). Logging of these species occurred 10 years ago in areas where the experimental plots were established. A young growth of red maple and white birch varying from 1.5 to $3 \mathrm{~m}$ in height formed the major, lower vegetation within the plots. The upper canopy was composed of mature red maples, grey birch (Betula populifolia (Marsl.)), and aspen (Populus tremuloides (Michx.)). Both habitats selected were identical in vegetation composition. All sampling plots were located in areas where deer browsing had been observed during the winters of 1975 and 1976 . The sprayed plots were treated with two aerial applications of three ounces active ingredient/hectare of fenitrothion in an oil emulsion between May 26 and June 3, 1977.

The sampling plots measured $10 \mathrm{~m}^{2}$. Samples were collected from the 15th of May through the 15th of November 1977. A total of 80 samples were collected and processed.

The browse samples were clipped with pole and hand pruners. About $10 \mathrm{~cm}$ were cut at random from terminal twigs ensuring a representative sampling of the entire tree. Twenty to $30 \mathrm{~g}$ were cut into small pieces and placed in $110 \mathrm{ml}$ glass bottles. While in the field, the bottles were filled with pesticide-grade ethyl acetate and covered with plastic snap lids which had previously been lined with alumininum foil. Within $2 \mathrm{hr}$ these bottles were refrigerated at $2^{\circ} \mathrm{C}$ until extraction.

Extraction of the insecticide and its derivatives from $20 \mathrm{-g}$ samples of foliage was accomplished within 15 days following the collection date. The macerated samples were placed in a Waring blender with enough ethyl acetate (pesticide grade) to bring the volume to $150 \mathrm{ml}$. Using an external rheostat, the sample was blended at gradually increasing speeds until it formed a pulp. A Buckner funnel (Reeve Angel) filter paper, and $2 \mathrm{~cm}$ pad of anhydrous $\mathrm{Na}_{2} \mathrm{SO}_{4}$ were used to separate solid plant residues from the extract. Plant solids remaining in the funnel were rinsed with ethyl acetate to ensure total recovery of the residue. The resulting darkgreen solution was evaporated to about $10 \mathrm{ml}$ in a $500 \mathrm{ml}$ round bottom boiling flask on a Buchli Roto evaporator. This residue was dissolved in $50 \mathrm{ml}$ of pesticide-grade acetonitrite, and was partitioned twice with $25 \mathrm{ml}$ of pesticide-grade hexanes. The polar layers were evaporated to about $20 \mathrm{ml}$ and placed on an activated charcoal column previously rinsed with $50 \mathrm{ml}$ presticide-grade benzene. A $20 \mathrm{~mm}$ ID column was used with the following packing: glass wool; $10_{\mathrm{g}} \mathrm{Na}_{2} \mathrm{SO}_{4}$ mixture of $9_{\mathrm{g}}$ activated charcoal $(\mathrm{BDH}), 6_{\mathrm{g}}$ Celite 503 and $10_{g} \mathrm{Na}_{2} \mathrm{SO}_{4}$. An electrical vacuum pump providing $270 \mathrm{~mm} \mathrm{Hg}$ suction was used for elution using $100 \mathrm{ml}$ benzene ethyl acetate (25:75), followed by $10 \mathrm{ml}$ benzene. The eluate was flushed to a small volume of about $10 \mathrm{ml}$ for analysis. This sample was refrigerated until analysis.

\section{Analysis}

Fenitrothion in the extract was analyzed by gas-liquid chromatogrophy done on a gas Tracor Model MT 270 equipped with an automatic sampler; Hewlett-Packard Model 7671 A with interface, and an automatic calculator Spectro physics auto Lab 1. The detector was a FPD system. Operating conditions of the gas chromatograph were: glass column $1.83 \mathrm{M} \times 0.64 \mathrm{~cm}$, column packing chromasorb W 80/100 mesh, liquid phase $3.6 \%$ OV 101 . The carrier gas was helium with a flow rate of $13 \mathrm{~kg} / \mathrm{cm}^{2}$.

\section{Results}

Results of the analysis as given in Table 1 are expressed in units of ppm as sampled. Due to insufficient time and funds, dried samples were not processed. The concentration of fenitrothion varied from $21.41 \mathrm{ppm}$ in the red maple to $19.37 \mathrm{ppm}$ in the white birch, immediately following the spray. The concentration within both species diminished rapidly following the spray application, and $\mathbf{3 0}$ days following the initial application, all concentrations were below 1 ppm.

The control plots were relatively free of contamination from the pesticide. The light concentration which appeared following the spray programs is more than likely due to aerial drift. The oxygen analogue of fenitrothion, fenitroxon, was detected in only two samples taken from the sprayed plots at concentrations of 0.004 and $0.15 \mathrm{ppm}$; no detection was obtained from the control samples. Results from both samples of browse indicate a persistence of the pesticide throughout the entire sampling period within the sprayed plots. However the concentration available to the deer during the browse period is considered to be below $0.010 \mathrm{ppm}$.

Table 1. Fenitrothion residues in red maples (Acer rubrum) and white birch (Betula papyrifera) deer browse for the 1977 aerial budworm spray program.

\begin{tabular}{|c|c|c|c|c|}
\hline \multirow{3}{*}{$\begin{array}{l}\text { Time relative to } \\
\text { application }\end{array}$} & \multicolumn{4}{|c|}{ Fenitrothion (ppm) } \\
\hline & \multicolumn{2}{|c|}{ Sprayed plots } & \multicolumn{2}{|c|}{ Control plots } \\
\hline & Maple & Birch & Maple & Birch \\
\hline - 15 days & 0.05 & 0.01 & 0.00 & 0.00 \\
\hline$-\quad 5$ days & 0.01 & 0.01 & 0.00 & 0.00 \\
\hline - Iday & 0.01 & 0.01 & 0.00 & 0.00 \\
\hline \multicolumn{5}{|l|}{ Ist Spray } \\
\hline$+15 \mathrm{~min}$ & 21.41 & 19.37 & 0.01 & 0.01 \\
\hline$+12 \mathrm{hr}$ & 16.72 & 14.20 & 0.01 & 0.01 \\
\hline I day & 11.32 & 9.02 & 0.01 & 0.01 \\
\hline 2 days & 8.76 & 7.79 & 0.01 & 0.01 \\
\hline 3 days & 5.31 & 6.33 & 0.01 & 0.01 \\
\hline 5 days & 1.82 & 2.44 & 0.00 & 0.02 \\
\hline+6 days & 0.97 & 3.41 & 0.00 & 0.01 \\
\hline+10 days & 0.79 & 1.22 & 0.00 & 0.00 \\
\hline \multicolumn{5}{|l|}{ 2nd Spray } \\
\hline+11 days & 19.39 & 9.31 & 0.01 & 0.01 \\
\hline+12 days & 12.03 & 3.21 & 0.00 & 0.01 \\
\hline+14 days & 7.63 & 2.42 & 0.00 & 0.02 \\
\hline 15 days & 3.28 & 1.02 & 0.00 & 0.00 \\
\hline 30 days & 0.74 & 0.09 & 0.00 & 0.00 \\
\hline 60 days & 0.06 & 0.07 & 0.00 & 0.00 \\
\hline+90 days & 0.02 & 0.03 & 0.00 & 0.00 \\
\hline+120 days & 0.02 & 0.01 & 0.00 & 0.00 \\
\hline+150 days & 0.01 & 0.01 & 0.00 & 0.00 \\
\hline
\end{tabular}

\section{Discussion}

Oral administration of ${ }^{14} \mathrm{C}$ fenitrothion at a dose level of 0.5 $\mathrm{mg} / \mathrm{kg}$ results in absorption of the pesticide and its appearance into the blood and internal organs of rats. However, after 4 days, the concentration in the blood was less than $.001 \mathrm{ppm}$ (Miyamoto 1969). Hollingworth et al. (1967) have indicated that the greater part of ${ }^{32} \mathrm{P}$ and ${ }^{14} \mathrm{C}$ fenitrothion is excreted in the urine within $24 \mathrm{hr}$ and that excretion is virtually complete with $96 \mathrm{hr}$. Barber and Nagy (1971) studied the influence of several pesticides on rumen bacteria of deer. With concentration of $1,10,100$, and $1000 \mathrm{ppm}$ of fenitrothion, cellulose digestion was respectively $83 \%, 63 \%, 25 \%$, and $12.6 \%$ of the control. After a period of $72 \mathrm{hr}$, all inhibition had ceased. Production of volatile fatty acids was little affected at 1 ppm or $10 \mathrm{ppm}$ of the pesticide. At $100 \mathrm{ppm}$, fenitrothion caused a slight decrease in fatty acid concentrations. Schwartz et al. (1973) studied the effects of certain pesticides on rumen function; they concluded that fenitrothion did not affect the digestion of dry matter and cell wall constituants.

In relating my findings to the work of the above authors, I can find no evidence to support the hypothesis that a concentration of fenitrothion of the magnitude, which 1 have detected in this study, would directly affect the white tail deer population of this area during winter yarding activities.

\section{Literature Cited}

Barber, T.A., and Nagy, J.G. 1971. Effects of pesticides on mule deer rumen bacteria. N.A. Wildlife Nat. Res. Conf. Trans. 36:153-162.

Crete, M. 1976. Importance of winter climate in the decline of deer harvest in Quebec. Can. Field-Nat. 90:404-409. 
Hollinzworth, R.M., R.L. Metcalf, and T.R. Fukuto 1967. The selectivity of Sumithion compared with methyl parathion Metabolism in the white mouse. J. Agr. Food Chem. 15:242-249.

Mlyamoto, J. 1969. Studies on the mode of action of organophosphorus compunds. Part IIl. Activation and degradation of Sumithion and methyl parathion in vivo. Agr. Biol. Chem, 28:411-421.

Nigum, P.C. 1971. Summary of laboratory evaluation of insecticides against forest insect pests during 1971. Chem. Control Res. Instit. Inf. Rep. CC-X-12. 14 p.

Schwartz, C.C., J.G. Nagy, and C.L. Streeter. 1973. Pesticide effect on rumen microbial function. J. Anim. Sci. 37:821-826.

Shishido, T., K. Usui, M. Sato, and J. Fukami. 1972. Enzymatic conjugation of diazinon with glutathion in rat and American cockroach. Pestic. Biochem. Physiol. 2:51-63.

Sundaram, K.M.S. 1974. Distribution and persistence of fenitrothion residues in foliage, soil and water in Larose Forest. Chem. Control Res. Instit. Inf. Rep. CC-X-64. 43 p.

Yule, W.N., and J.R. Duffy. 1972. The persistence and fate of fenitrothion insecticide in a forest environment. Bull. Environ. Contam. Toxicol. 8:10-18 